\title{
Understanding "Koreanness": Racial Stratification and Colorism in Korea and Implications for Korean Multicultural Education
}

\author{
Hyein Amber Kim \\ State University of New York (SUNY) \\ Buffalo, New York \\ U. S. A.
}

\begin{abstract}
This paper explores the social construct of Koreanness and its implications. The first section reviews literature on Whiteness, and states that Koreanness shows many similarities to Whiteness in the United States. Next, drawing upon the framework of Bonilla-Silva, this paper argues that a tri-racial system is emerging in Korea, with Koreanness at its center. Then, the study examines how racism and colorism permeate Korean society and culture, with special attention to education. The paper concludes that Koreanness should be addressed in multicultural education in Korea: in teachers' reflection of their identities, teacher education, instruction, and anti-racism curriculum.
\end{abstract}

KEYWORDS: Koreanness, multicultural education, Korean education, racism, colorism

\author{
Parallels Between Whiteness and Koreanness \\ Korean Racial Order and Colorism \\ The Norm of Koreanness \\ Implications for Multicultural Education in Korea \\ References \\ Author Contact
}

For the past two decades, the growing damunhwa (literally, "multicultural") population has been at the center of debate in the South Korean national discourse about immigration. South Korea (hereafter Korea) has long prided itself on being homogenous in its race and culture (N. Kim, 2014). However, with the sharp increase in the foreign and mixed-race Korean population, it was inevitable that the Korean government would address this issue. The term damunwha emerged in this process, and was used to describe families, children, and, in the case of education, students, that were foreign workers, marriage immigrants and their children, mixed-race Koreans, and North Korean refugees. Despite the heavy support from the Korean government for damunhwa families and children, the fundamental problem remained: people who were dubbed "multicultural" were in fact ousted as being the non-Korean Other. Hence the approaches and efforts of the government reproduced "the cultural hierarchy between Koreans and non- 
Koreans" rather than dismantling it (Kim, Basile, Jaime-Diaz, \& Black, 2018, p. 1538).

But what exactly does it mean to be Korean? According to literature on Korean identity and culture, there are at least three elements of a Korean identity: having Korean blood, knowing and using the Korean language, and understanding Korean culture and customs. This is consistent with ethnic nationalists who contend that "nations are determined by a shared heritage," which usually includes a common ethnic ancestry, common language, and a common faith (Muller, 2008).

Korean blood lineage is an important part of Korean identity. The grounds for citizenship in Korea lie heavily on jus sanguinis, the 'right of blood.' Although there has been a recent move to jus domicile, citizenship based on "law of residence" and multiculturalism, the cultural understanding of who a Korean is is still deeply embedded in the belief that one is Korean by Korean blood (N. Kim, 2014). In fact, the deep-seated sunsuhyeoltongjui ('pure blood' theory), which was used as a nation-building ideology after the post-Japanese colonial period, clashes with the various immigration issues the country is dealing with to this day. The notion that Koreans originated from a single, pure bloodline is reflected in the country's educational curriculum and textbooks as well. The U.N. Committee on the International Convention Elimination of All Forms of Racial Discrimination took notice of the discrimination caused by this theory and urged the Korean public education system to overcome the notion that Koreans were "ethnically homogeneous" as it did not reflect the actual situation in the country (Choe, 2009).

The Korean language is another element in the construction of a Korean identity (Cho, Cho, \& Tse, 1997; Kang \& Kim, 2012; Kim, Lee, \& Kim, 1981; J. S. Lee, 2002; You, 2005). Many Koreans believe that the Korean language holds great symbolic importance and can be considered an "embodiment of the Korean national identity" (Simpson, 2007, p. 233). Because of this belief, the Korean Ministry of Education (2017) continues to support multicultural students with a Korean language curriculum for Korean language and culture.

Cultural knowledge and the understanding of Korean culture's central characteristics are also considered an element for being Korean. But the mere possession of cultural knowledge about Korea is not the end with respect to asserting a Korean identity. Rather, an individual must personally endorse Korean culture's shared knowledge and align and agree with its most important and widely shared cultural values, beliefs, norms, and practices in order to identify with being Korean (Wan \& Chew, 2013). This widely shared, dominant understanding of Korea and what it means to be Korean is maintained through external cultural carriers such as social institutions, the media, language, and the arts (Lamoreaux \& Morling, 2012). The dominant 'official' cultural knowledge of who a Korean is and what that entails is not only in the overt and hidden curriculum in Korean schools (Kang, 2015), but also distributed and perpetuated in popular media and educational policies.

The issues of blood lineage, language, and cultural knowledge have been widely discussed in the discourse of who a Korean is. However, there is a racial 
aspect that is not extensively discussed in the discourse of Korean membership, culture, and citizenship. Race, skin color, and physical appearance often work conjointly with the other elements of a Korean identity. This Korean skin privilege, which I call "Koreanness," works much like the racial construct of Whiteness in the U.S. in the sense that it differentiates Koreans and non-Koreans, and grants privileges and unearned advantages upon those who fit the description of Korean. However, there is limited literature on this normalized, skin color-privileging mechanism in Korea, especially in the field of education. In this article in order to better understand the social construct of Koreanness, I first examine Whiteness in the U.S. context to see if I can draw parallels between the two. Although there are many dissimilarities between the U.S. and Korea in the collection of racial and ethnic groups, some of the essential themes that emerged from the Whiteness scholarship are also helpful in understanding Koreanness in Korea. Next, through the framework of Bonilla-Silva (2004), I investigate the racial hierarchical system of Korea, which has Koreanness at its center. Then, I describe how Koreanness operates in the Korean society and culture. In the final section, I examine how Koreanness operates in the Korean education field and the implications for teacher education in Korea.

\section{Parallels Between Whiteness and Koreanness}

\section{Examining Whiteness}

I use Whiteness in this article to mean the ideology and experiences of those who are categorized as being of the White race and White skin. The Oxford Dictionary (2018) defines Whiteness as "the fact or state of belonging to a human group having light-coloured skin." The definition of Whiteness I use in this article is not limited to skin color, however, but rather encompasses the identities, beliefs, values, and ideologies behind this concept (Doane \& Bonilla-Silva, 2013; Frankenberg, 1993; Kivel, 1996). As Whiteness scholars have pointed out, Whiteness reflects the position of power and dominant group status (Hill, 1997; Wellman, 1993). Recent scholars expand the definition of Whiteness and situate it in the context of intersectionality; I will not discuss it in depth since this would go beyond the scope of the present article.

Whiteness cannot be discussed without acknowledging the significance of race in the United States. Omi and Winant (2015), as part of their theory of racial formation, wrote about how racial projects assign meaning to race and situate it in the larger U.S. society. Within the racial hierarchy that is formed, Whiteness is valued above all others. Whiteness occupies a privileged place in the mechanism of race. Guess (2006) wrote that "race is a social fact in which the social and political significance of whiteness plays a critical role" (p. 654). Because both paradigms of race and Whiteness are socially constructed, they also change over 
time (Andersen, 2013; Delgado \& Stefancic, 2001; Foucault, 1972; Jacobson, 1998; Ladson-Billings, 2004).

A major theme that emerges from Whiteness literature is that Whiteness is the norm (Garner, 2006; McIntosh, 1989; Wilson, 2002). There is a deeply ingrained belief in the U.S. that the culture, language, and appearance that characterize White is normative. This echoes the assumption of Critical Race Theory (CRT) that, much like the social construct of race, Whiteness is so deeply ingrained in the culture that "it looks ordinary and natural to persons in the culture" (Delgado \& Stefancic, 2001, p.xvi). This seemingly natural barometer of Whiteness leads to distinguishing those who are not White as racial or ethnic. Critically examining, exposing, and challenging this concept of Whiteness is crucial. The normality of Whiteness enables it to maintain a hegemony over all races. Du Bois (1915) stated that there is a natural assumption in society to situate Whiteness as the norm and race of power. He wrote, "Most persons have accepted that tacit but clear modern philosophy which assigns to the white race alone the hegemony of the world" (p. 139).

White privilege is another major theme that emerges from Whiteness literature. Scholars of Whiteness Studies such as Dyer (1997), Frankenberg (1993), McIntosh (1989), and Rothenberg and Munshi (2016) have examined Whiteness as a system of privilege that plays out on many different levels. They argue that White people are granted benefits and have greater access to power and resources than do people of color. McIntosh (1995) states that those who are White experience this privilege on a daily basis, solely based on skin color. She points out that White privilege is "unearned power conferred systematically" (pp. 82-83) and forms a structure of advantage and disadvantage. Kivel (1996) writes that Whiteness is "a powerful fiction enforced by power and violence" (p. 19). Whiteness scholars argue that recognizing White privilege is not enough; there must be a deeper understanding of the racism and racial stratification that is the basis of this White privilege.

\section{Defining Koreanness}

The U.S. and Korea have distinct histories, people, and cultures. Thus, Koreanness is not similar to Whiteness in every respect; however, the themes that emerge from Koreanness and Whiteness are similar: both are socially constructed concepts of racial superiority in order to justify discrimination against minority members, and they change over time with each new wave of immigration and change in demographics. Much like Whiteness, Koreanness can be critically examined in the context of intersectionality (i.e., intersections of Koreanness with other power relations such as gender, class, sexuality, etc.); however, this will not be discussed in depth here since the present article focuses on the construct of Koreanness as it relates to racial stratification and colorism in Korea.

I define Koreanness in this article as belonging to or having Korean skin color. Korean skin color can be described as a yellow to red tone. However, much like Whiteness, skin color alone does not determine the implications of Koreanness because racialization is complex. Telles and Paschel (2014) argue that skin color 
is the most important characteristic associated with race. Korean skin color is one of the important characteristics used in racial categorization and identification in Korea. The reason that Koreanness must be examined is because at its heart are race, racism, colorism, and Korean privilege. Thus, the definition of Koreanness in this article is not limited to merely skin color, but encompasses the identities, beliefs, values, and ideologies behind the concept. The closer one is to having Korean skin color, the more possible it is to access power and privilege.

Critical Race Theory (Bell, 1980; Delgado \& Stefancic, 2001; Gillborn \& Youdell, 2009; Ladson-Billings, 2004) and Whiteness literature (Hill, 1997; Mclntosh, 1989; Wellman, 1993) are framing ideas and informing literature to understand Koreanness. The idea of race neutrality - the belief that Korean is the norm and default-operates in Korean society and culture, much like the way Whiteness operates in the United States. Until recently, the term salsaek ("skin color") was widely used to describe the skin color of general Koreans. There is a strongly imagined belief of racial homogeneity in Korea, and thus it was believed there was only one single skin color of the Korean race. In Korean schools, it was common to see students use salsaek crayons when coloring people (Park, 2018). In 2002, the National Human Rights Commission of Korea (2002) announced that the name of the color, salsaek, was violating the rights of equality of those who were not of the Yellow/Mongoloid race, with no reasonable grounds. Following this announcement, the Korean Agency for Technology and Standards revised the Korean Industrial Standards to reflect this amendment, and from 2005 all salsaek crayons were named salgusaek ('peach color') or light orange-color instead (Park, 2018). It is crucial to examine Koreanness, its effects and implications, in the context of critical multiculturalism.

\section{Korean Racial Order and Colorism}

\section{Skin Color and Racial Hierarchy in Korea}

In order to challenge Koreanness as the foundation of racism and colorism, it is necessary to understand the history of race in Korea that is tied with skin color. Skin color and racial categorization have long been present in the Korean language when describing non-Korean 'Others'. For example, the word baekin, which is a combination of the two words baek ("white") and in ("person") literally means "white person" and is used to describe people who are racially White. When describing people of African descent with darker skin color, Koreans use the word heukin, literally translated as "black people," to describe people belonging to the racial category. With the change in demographics, the racial categories have changed, along with the language surrounding them as well.

Prior to the wave of migrant workers in the 1990s, the Korean racial order was closer to a binary system consisting of Koreans and non-Koreans. Koreans, since establishing the government in 1948, had little or no exposure to foreign 
culture until they hosted the 1986 Asian Games and the 1988 Olympic Games (Oh et al., 2012). However, from the late 1980s, Korea experienced a period of industrialization and advancing income levels, which led to a shortage of lowskilled workers. To address this issue, the Korean government started to actively accept foreign workers under the Industrial Trainee System in the early 1990s (Roh, 2014). These foreign workers, who were mostly from Southeast Asian countries, worked in the "3D (difficult, dirty, and dangerous)" industries in Korea; they were employed in factories, construction sites, and the service industry (Ock, 2018). During this process, racial projects occurred and were dispersed in Korea to form categories of race (Omi \& Winant, 2015): the Korean race and "foreign" race.

Since the 2000s, international marriages and marriage migration have increased, leading to a more diverse non-Korean population. With more young Korean women leaving rural towns for higher-paying jobs in the cities, young Korean men were often left to take care of the family farms (Choe, 2005). This led to an increase of international marriages between Korean men and foreign women from countries such as Vietnam, China, and the Philippines, among others ( $M$. Kim, 2019). The increase of "marriage migrant women" and international marriages has resulted in the increase of multicultural families and mixed-race children. The increase in population of foreign migrants and mixed race Koreans has resulted in more shades of skin color. This led to a change to the racial hierarchy, although still with Koreanness at the center. With the growing diversity of Koreans, the Korean-foreign racial landscape shifted from a binary racial order towards a triracial system, much like Bonilla-Silva's (2004) framework.

Bonilla-Silva (2004) argues that with the "darkening" of the United States, the bi-racial hierarchy typical of the United States is evolving into a complex and loosely organized tri-racial stratification system similar to Latin American countries. In the tri-racial system that Bonilla-Silva proposes, "Whites" are at the top; "Honorary Whites", minorities who "approximate or even surpass Whites in terms of many measures" (e.g., light-skinned Latinos and Americans of Asian descent) are in the middle; and the non-White group, the "Collective Blacks" (e.g., Blacks, dark-skinned Latinos, Vietnamese) are at the bottom (Bonilla-Silva, 2004, pp. 932933). The "mixing" of skin colors in Korea has led to a racial project (Omi \& Winant, 2015 ) in which the racial order is slowly "reshuffling," resulting in a more complex racial hierarchy, much like the one Bonilla-Silva proposed. Similar to the Latin American tri-racial system, color gradations, phenotype, and class status are important factors in bestowing racial statuses (Glenn, 2009) in Korea.

It is impossible to fit everyone in Korea into the tri-racial order that I have presented in Figure 1; however, it is a guide to better understand the overt and covert discrimination that people of color experience in Korean society because of their skin color and race. Drawing on the important work by Bonilla-Silva (2004), I hypothesize that the Korean tri-racial system is comprised of 'Koreans' at the top, an intermediary group of 'honorary Koreans', and a dark-skinned Korean and nonKorean group 'collective dark' at the bottom. In the Korean tri-racial system, 'Koreans', and only 'pure blood' Koreans, are considered to be at the top of the 
hierarchy. This is not only because of the emphasis on Korean blood lineage, but also because of the current demographics of the country. According to the Korea Immigration Service (2018), in the year 2017, 95.79\% of the Korean population were racially/ethnically Korean with $4.21 \%$ of the Korean population being foreign nationals (including foreign residents and undocumented immigrants). While the mixed race Korean population is not included in the foreign national population, they are also not socially and culturally accepted as Koreans. In Korean society, only 'pure-blood' Koreans and racial/ethnic Koreans residing outside of Korea may be included in the 'Korean' category.

\begin{tabular}{|l|}
\hline \multicolumn{1}{|c|}{ "Koreans" } \\
Koreans "Honorary Koreans" \\
Racial/ethnic Koreans residing outside of Korea \\
\hline \multicolumn{1}{c|}{$\quad$ "Collective Dark" } \\
East Asian immigrants \\
Light-skinned Central Asians \\
Korean-East Asian multiracials \\
Korean-White multiracials (i.e., 'honhyul' individuals) \\
Light-skinned non-Koreans \\
\hline \multicolumn{1}{c}{ Southeast Asians immigrants } \\
South Asian immigrants \\
Middle Easterners Kark-skinned non-Koreans \\
Korean-Southeast Asian multiracials (i.e., 'damunhwa' individuals) \\
Korean-Black multiracials \\
Blacks
\end{tabular}

Figure 1. Preliminary Map of Tri-racial System in Korea. Adapted from BonillaSilva, 2004.

The intermediate racial group or 'honorary Koreans' comprises East Asian immigrants (Chinese, Japanese, etc.), light-skinned Central Asians (Uzbekistanis, Kazakhstanis, etc.), Korean-East Asian multiracials, Korean-White multiracials (who are now referred to as honhyul), and lighter-skinned non-Koreans (including White or light-skinned Americans, Australians, Europeans, South Africans, etc.). While the Korean immigrant population is diverse, just a few countries of origin make up a large share of the total. According to the Korea Immigration Service (2018), there have been a growing number of foreign nationals from China, accounting for $46.2 \%$ of the total immigrant population in 2017. The evolving of the honorary Korean category to include East Asians is largely attributed to the shift in the demographics of immigrants to Korea. 
Finally, the 'collective dark' group may include Southeast Asian immigrants (Vietnamese, Thai, Filipino, etc.), South Asian immigrants (Indian, Pakistani, etc.), Middle Easterners, dark-skinned non-Koreans, dark-skinned multiracial Koreans, and Blacks. The second and third largest groups of foreign residents in Korea were from Vietnam (8.1\%) and Thailand (7.7\%) (Korea Immigration Service, 2018). Not only are the foreign nationals from these countries considered the 'collective dark', but mixed-race Koreans with parents from these countries are as well. Also, because the Korean government keeps track of foreign residents not by their race but rather by their nationality, it is difficult to accurately know the Black population in Korea. Although there are more Black and half-Korean/half-Black individuals represented in Korean popular media, the unfair treatment and discrimination they face on an everyday basis should not be overlooked.

\section{Colorism in Korea}

Skin tone-the shades of skin color-is important in discussing Koreanness. Research and theory by Dixon and Telles (2017) indicate that much of the current literature on Asian societies emphasizes the role of classism and aesthetics in skin color preferences prior to Western contact. Dixon and Telles (2017) also state that in Japan, Whiteness held a symbolic meaning due to its ties with class privilege, spiritual purity, and feminine beauty. While many scholars have discussed colorism in the Asian and Asian American community (Dixon \& Telles, 2017; Jones, 2013; Rondilla \& Spickard, 2007), few have explored colorism in the Korean context.

Historically, Koreans considered those of lighter skin to be more desirable, as skin color represented one's social status. As Glenn (2009) pointed out, in many Asian societies, skin color was long seen as a sign of social class. Elites and aristocrats who were educated were imagined to stay indoors reading and studying, and thus had lighter skin; on the other hand, commoners and servants who were uneducated worked out in the sun, laboring outdoors. There was a gender layer to this skin tone hierarchy as well. Korean men with darker skin "got a pass for being providers," but a woman had to be white without blemish to "prove both her beauty and her virtue" (Tharps, 2016, p. 117). Moreover, for women, lightness was associated with desirability, femininity, beauty, and purity (Hall, 2010; Rondilla \& Spickhard, 2007).

Colonialism and Western imperialism have heightened this notion that lighter-skinned people are more desirable. In their book, Is Lighter Better?: Skintone Discrimination among Asian Americans, Rondilla and Spickard (2007) share a powerful story from a Korean American woman:

My father used to call me 'Snow White' while he would call my sister 'Dark Princess.' Even though, according to him, we were both princesses, we knew there was a hierarchy. Somehow, as little children, we understood that being lighter was better. (p. 9) 
Skin color bias and colorism is still a growing issue in Korea with an increasing immigrant population and a growing number of multiracial Koreans whose skin color varies. According to the Ministry of Justice (2016), as of 2015, migrant workers made up the largest group of foreign nationals in Korea (approximately $42 \%$ ), and migrants married to Korean spouses were the second largest group (approximately 10.2\%). Foreign migrant workers and marriage migrant women come mostly from Southeast Asian countries or regions in China, where people tend to have relatively darker shades of skin color compared to Korea. Given this context, residents in Korea who belong to the 'collective dark' group experience an interplay of inequalities and stigma, as they sit at the intersections of race, skin color, nationality, class, and gender (Crenshaw, 1989). A recent study showed that Koreans' perceptions towards foreign migrant workers are worsening (Ock, 2018). Migrant workers are subject to intersectional discrimination as they are working-class, dark-skinned, non-native Korean speaking "foreigners," perceived to be from 'developing countries'. Moreover, nonKorean workers are not protected from discrimination in wages. In fact, a recent study found that South Korea has the biggest wage gap between native and foreign-born workers among member countries of the Organization for Economic Cooperation and Development (Ock, 2015). To this end, further research should examine the complex and cumulative ways different forms of discrimination overlap and affect diverse groups of Koreans.

\section{The Norm of Koreanness}

\section{Koreanness in Korean Society and Culture}

On the national level, Korean skin color is at the crux of the Korean national identity, along with Korean language and Korean blood lineage. In other words, in order to be considered Korean, one must be of Korean lineage, speak and utilize the Korean language, and look Korean. Koreans have long believed themselves to be a danil-minjok ('single-race people/nation'), sharing a common bloodline. Hence, traditionally, all Koreans are imagined to share similar physical features such as Korean skin color, "black, coarse, and straight" hair (J. C. Kim, 2010, p. 21), "small and elongated eyes," and a "relatively flat face" (Oh, 2014, p. 64).

With the growth of the immigrant and multiracial population, certain terms emerged that were used to distinguish Koreans from non-Koreans. The term damunhwa ('multicultural'), as discussed earlier, became a commonly used word to refer to those of multicultural backgrounds, including non-Korean immigrants and mixed race Koreans. This term differentiates those who are Korean, the default, invisible norm, from those who are not. Also, the term honhyul ('mixed blood'), which is also used to describe those of mixed race backgrounds, is juxtaposed with sunhyul ('pure blood'), which describes Koreans. Both termsdamunhwa and honhyul- are used to describe individuals of non-Korean 
backgrounds who do not look Korean. While the two terms were used interchangeably in the past, there has been a shift in which honhyul is now used to identify lighter-skinned, "White-skinned" Koreans, and damunhwa is used to identify dark-skinned Koreans (Ahn, 2014).

The Korean political sphere is not only a gendered space, but a racialized and colorized one as well. The majority of elected officials are Korean and male. According to G. Lee (2015), only $16.3 \%$ of Congresspeople in Korea were female in 2015, and only one of them was a woman of color (non-Korean): Jasmine Lee, the first ever foreign-born South Korean Congressperson from the Philippines. Dark skin is a sign of "perpetual foreignness" in Korea, a sign that one is an outsider who cannot be a "true" Korean despite one's citizenship or Korean blood tie (Ahn, 2017). Hence Jasmine Lee quickly became the "one of the most hated women in Korea" (D. Kim, 2015), as it was perceived that she was representing the entire foreigner and damunhwa population in Korea, which constitutes approximately four percent of the Korean population (Volodzko, 2017).

Korean media is another area that reflects and perpetuates Koreanness. In major Korean news channels, TV shows, dramas, movies, and entertainment shows, most, if not all, individuals who are cast are Korean or those who look Korean. While there is an increasing representation of people with non-Korean skin color in Korean media, their portrayals are limited and unbalanced. For example, a popular Korean TV show, The Return of Superman, follows celebrity fathers who take care of their child/children for 48 hours without their wives. While most celebrity fathers and their families have been Korean, there have been several celebrities who have mixed race Korean children that have been the spotlight of the show. For instance, White Australian Sam Hammington appears on the show with two of his half-White/half-Korean sons, William and Bentley. Recently, Korean soccer player, Park Joo-ho, and his half-White/half-Korean daughter and son appear on the show, and the Korean media are celebrating the fact that the show is pioneering in the acceptance of mixed race Koreans. However, the non-Koreans that are cast on the show are all White, while the mixedrace Korean children have lighter skin color (Shin, 2018). While there is a large percentage of mixed race Koreans with darker skin complexions, they are nearly impossible to find on this show or in Korean media in general.

\section{Koreanness in the Korean Education System}

Koreanness permeates and saturates the educational field. In the Korean public school system, the vast majority of public school teachers are Korean, and almost all teachers who teach the Core Curriculum are Korean. In fact, Koreans serving as public school teachers is such a norm that when a dark-skinned halfKorean/half-Indian, Yerin Vasudevi, became a public elementary school teacher, it gained national attention (Yoon, 2018). Vasudevi recalled that when she attended school, she was often teased and discriminated against for her darker 
skin complexion. The lack of diversity in the teacher population, however, is not the only issue.

Discrimination based on skin color is prevalent in Korean classrooms. The school dropout rate for students of multicultural backgrounds is four times higher than that of their Korean peers (Chang, 2018). Peer relationships, lack of interest in school material, low Korean language proficiency levels, discrimination from the teachers, lack of parental support, financial difficulties, and physical appearance are all factors that contribute to the dropout rate (S. Y. Lee, 2018). The common misconception Koreans have is that multicultural students drop out of schools due to their low level of Korean language proficiency. However, multicultural students report that their relationships with peers and teachers were the primary factors when they decided to drop out of school (Kwon, 2015). The level of school bullying, harassment, and discrimination that multicultural students experience from peers has increased despite the increase in diversity in the classrooms (Ahn, 2019; H. Lee, 2019). Although many of the multicultural students report that they experience bullying and discrimination based on their skin color, parents' national background and language, or religion, there is a lack (or absence) of school-wide anti-bullying programs or comprehensive intervention and prevention practices in place (Cho, 2018).

In addition, despite the growing diversity of the student population, Korean teachers are unprepared and under-resourced to be multicultural educators (Yeo, 2016). Reports show that instead of creating a safe, inclusive learning space, some Korean teachers call out mixed race or non-Korean and immigrant students by using derogatory words and humiliating them in front of the class (J. H. Kim, 2018). Various media reports have covered teachers' attitudes and perceptions, as well as teachers' deficit perspectives and discrimination towards non-mainstream Korean students, especially multicultural students of different racial and cultural backgrounds. For example, when calling on multicultural students, some Korean teachers were reported to use "damunhwa" or students' home countries (e.g., "China" or "Vietnam") instead of their individual names, clearly labeling and grouping non-mainstream Korean students as 'alien' or Other (Park \& Park, 2018). In other cases, teachers were reported to have called out multicultural students for not being "Korean enough" ("Damunhwa haksaenge", 2015). In most cases, the students who were victims of racially charged remarks from teachers, were 'collective dark' students, students of darker skin color; incidents that reported on teachers' discriminatory behaviors towards lighter-skinned, 'honorary Korean', students could not be found (or were rarely documented).

The curriculum in Korea reflects the invisible norm of Koreanness as well. Although the Korean Ministry of Education has established guidelines for textbooks and curriculum to include multicultural instruction and global citizenship education (Presidential Committee on Social Inclusion, 2006, p. 9), the number of textbook revisions that reflect this is limited. Also, textbook content and images that depict non-Koreans are still essentialist and stereotypical (Y. Kim, 2013). For example, in a Korean 5th grade social studies textbook, illustrations of "foreigners enjoying Korean cultural activities" are portrayed by lighter-skinned characters, while 
"foreign migrant workers" are portrayed by darker-skinned characters (C. Lee, 2019; H. S. Lee, 2018). Illustrations of "Western" individuals (e.g., English teachers) in textbooks are light, white-skinned characters with blonde hair and high nose bridges as well (H. Kim, 2012).

Representation of non-Korean teachers is slowly growing in Korean public schools; however, they are perceived as 'foreign' teachers and are limited to noncurricular language classes, or after-school and extracurricular lessons. The majority of non-Korean teachers in Korean public schools are native speakers of certain languages and are usually paired with a Korean teacher that teaches the target language in Korean. Many of these 'multicultural teachers' are not only treated as 'foreign' but are also underpaid, and do not receive the same benefits as their Korean counterparts (J. R. Kim, 2018).

\section{Implications for Multicultural Education in Korea}

Prior to the 2000s, the majority of students in Korean public schools were mainstream Korean students; there was little racial or ethnic diversity. The increase of migrant workers and international marriages since the 2000s led to a sharp increase in mixed race Korean and non-Korean students in the public education system, making it necessary for Koreans to adapt their educational system to reflect the newly emerging multicultural environment (Kim \& Kim, 2012). While the term damunhwa gyoyuk ('multicultural education') is widely used in Korea, current multicultural education in Korea aims primarily at better assimilating non-mainstream Korean students into dominant Korean culture.

One of the goals of multicultural education is for schools to transform and change to create an environment where all students may learn and access equal educational opportunities (Banks, 1999; Banks \& Banks, 2013; Grant \& LadsonBillings, 1997; Keddie, 2012). Meaningful changes towards critical multicultural education in Korea must be made on the institutional level as well as the personal and instructional levels in order for students to better understand and appreciate cultural differences and diversity. However, in Korea, much of the responsibility for interpreting and implementing multicultural education policies still lies on the teachers. Following are a few suggestions, on both personal and instructional levels, for teachers.

Teacher identity and teacher reflection are important parts of multicultural education (Li, 2007; Rieger, 2015). In order for Korean teachers to bridge the gap between the Korean mainstream culture of schooling and diverse learners who aren't members of the mainstream culture, it is essential for teachers to reflect on their own racial identities and Koreanness in a society that systematically privileges the Korean race and Korean skin color. This requires teachers to acknowledge and understand the sociopolitical context (Nieto, 1996) of Korean education, understanding the structural inequality and stratification in education due to social class, gender, ethnicity, and other differences (including race, which is not 
examined enough in Korea) and the codes and culture of power at the core (Delpit, 1995; Gillborn \& Ladson-Billings, 2004). Korean pre-service and in-service teacher education programs may include methods such as self-study and personal narratives (e.g., autoethnography assignments) in the context of critical pedagogy. These may provide opportunities for teacher educators to "make sense of their own identities, dispositions, and assumptions in the context of teaching for diversity" (Schulte, 2004, p. 720) and "use this personal and social knowledge to consider their pedagogical dispositions and practices" (Vavrus, 2009, p. 386). In other words, Korean teachers' critical self-exploration may lead to personal and professional implications of transformative knowledge for teaching practices (Schulte, 2004).

Teachers' professional development programs in Korea must also help teachers challenge their own attitudes, beliefs, pedagogies, and biases regarding race, racism, colorism, and different forms of social injustices (Gay, 2010). Increasing numbers of reports on teachers' racially insensitive comments towards multicultural students demonstrate the underlying prejudices teachers have about darker-skinned, 'collective dark' students versus lighter-skinned, 'honorary Korean' students. Supporting teachers' Korean journey to racial awareness may help teachers monitor their (un)intentional and racially biased behavior, as well as support them to create a safe environment of inclusion and equality for all students. In addition, teacher development programs must provide teachers tangible applications (e.g., in-class activities) of theoretical ideas about race (Pollock, Deckman, Mira, \& Shalaby, 2010). For instance, Adams, Bell and Griffin (2007) offer "logical" or "psychological" sequences of learning activities to introduce students to concepts on race and ethnicity in a safe and effective manner (e.g., low-risk activities involving individual reflection and discussion in pairs or small groups).

Korean teachers also need to recognize students' cultural and racial diversity in the classrooms. Irvine (1990) argues that when the tools of instruction (i.e., books, teaching methods, and activities) are incompatible with, or worse, marginalize the students' cultural experiences, it is probable that students feel a disconnect with school. Culturally responsive pedagogy acknowledges and engages diverse learners and their experiences, identities, styles of learning, and communities (Foster, 1997; Gay, 2002; Ladson-Billings, 1995; Villegas \& Lucas, 2002). For Korean teachers to be culturally relevant and responsive, they should draw upon and value students' funds of knowledge in the classroom (González, Moll, \& Amanti, 2005). This means teachers are integrating the cultures and identities of immigrant students, multicultural students, and North Korean refugee students into their instruction. For example, one out of ten foreign residents in Korea is Muslim (Liu, 2015) and 12\% of the foreign student population in higher education are Muslim (J. Y. Kim, 2019). Given this context, a class about religions may be transformed to an interactive class exploring diverse religions within Korea and different places of worship in students' communities. Incorporating funds of knowledge in the classroom is not only for non-mainstream students, but for all Korean students. 
Finally, an anti-racism, anti-colorism curriculum should be provided in classrooms so that all Korean students may examine and critique Koreanness as an integral aspect of educational discourse. Multicultural education in Korea should move beyond merely tolerating, celebrating, and co-existing with 'Other' students. Multicultural education should include exploring inequalities, stereotypes, and discrimination, and should teach social justice. As a start, this type of social justice curriculum for students may be incorporated in bullying prevention programs in the Korean general curriculum. Grant and Sleeter (2006) called on teachers to address power and privilege in the classroom, to subvert dominant hegemony, purposefully teach about injustices, and ensure educational equity for all students. Consistent with Grant and Sleeter's approach, Korean teachers should make Koreanness visible and explore Korean privilege in classrooms to help students and educators work towards dismantling beliefs, stereotypes, and practices that reproduce social and educational injustice. Discussions on Koreanness should not be limited to the issues of race or ethnicity; but rather should include critical examinations of power, privilege, racism in Korea, Korean identity, and intersectionality. This approach to multicultural education-transformative multicultural citizenship education-will help students to develop critical thinking skills and gain tools to combat discrimination and work towards social justice, not only in Korea but in the world.

\section{References}

Adams, M., Bell, L. A., \& Griffin, P. (2007). Teaching for diversity and social justice: A sourcebook (2nd ed.). New York, NY: Routledge.

Ahn, M. (2014, June 19). Hayanpibuneun 'honhyul', kkaman aineun 'damunhwa'...Hangukineui ljungjatdae [White skin color is 'honhyul', black skin color is 'damunwha'...Koreans' double standards]. Baby Times. Retrieved from http://www.babytimes.co.kr/news/articleView.html?idxno=3629

Ahn, S. Y. (2019, May 2). Damunhwa gajok, jangi geuju neurutda...hakgyo pokryuk·chabyuleun simhaejyu [Multicultural families' long-term residency has increased...school bullying and discrimination are worse]. Chosun llbo. Retrieved from http://news.chosun.com/site/data/html_dir/2019/ 05/02/2019050201362.html?utm_source=naver\&utm_medium=original\&ut m_campaign=news

Andersen, M. L. (2013). Whitewashing race: A critical perspective on Whiteness. In A. W. Doane \& E. Bonilla-Silva, White out: The continuing significance of racism (pp. 21-34). New York, NY: Taylor and Francis.

Banks, J. A. (Ed.). (1996). Multicultural education: Transformative knowledge and action. New York, NY: Teachers College Press.

Banks, J. A., \& Banks, C. A. M. (2013). Multicultural education: Issues and perspectives (8th ed.). Hoboken, NJ: John Wiley and Sons.

Bell, D. A. (1980). Brown v. Board of Education and the interest convergence dilemma. Harvard Law Review, 93(3), 518-533. 
Bonilla-Silva, E. (2004). From bi-racial to tri-racial: Towards a new system of racial stratification in the USA. Ethnic and Racial Studies, 27(6), 931-950.

Cho, Y. J. (2018, November 25). Incheon damunhwa hakseng 6cheon7baekmyung...hakgyopokryuk boho program upda $[6,700$ multicultural students in Incheon... no anti-bullying programs]. Joongboo Ilbo. Retrieved from http://www.joongboo.com/news/articleView.html? idxno=1305836

Cho, G., Cho, K., \& Tse, L. (1997). Why ethnic minorities want to develop their heritage language: The case of Korean-Americans. Language, Culture and Curriculum, 10, 106-12.

Choe, S. (2005, June 24). Foreign brides challenge South Korean prejudices. The Korea Herald. Retrieved from https://www.nytimes.com/2005/06/24/ world/asia/foreign-brides-challenge-south-korean-prejudices.html

Choe, S. H. (2009, November 1). South Koreans struggle with race. The New York Times. Retrieved from https://www.nytimes.com/2009/11/02/ world/asia/02race.html

Chang, M. H. (2018, June 17). Seotun hangukuheh ddadollimae...hakgyo ddunaneun damunhwa iedeul [Poor Korean language skills and bullying...Damunhwa children who are leaving the schools]. Yonhap News. Retrieved from http://www.yonhapnews.co.kr/bulletin/2018/06/15/ 0200000000AKR20180615124100797.HTML?input $=1195 \mathrm{~m}$

Crenshaw, K. (1989). Demarginalizing the intersection of race and sex: A Black feminist critique of anti-discrimination doctrine, feminist theory and antiracist politics. University of Chicago Legal Forum, 1989(1),139-168.

Damunhwa haksaenge "Kimchido mot muknya" gyosa yujwe [Teacher found guilty who said "Can't you even eat kimchi?" to multicultural student]. (2015, February 12). YTN. Retrieved from https://news.naver.com/main/read.nhn ?mode $=$ LPOD\& $\mathrm{mid}=$ tvh\&oid $=052 \&$ aid $=0000655056$

Delgado, R., \& Stefancic, J. (2001). Critical race theory: An introduction. New York, NY: New York University Press.

Delpit, L. (1995). Other people's children. New York, NY: The New Press.

Dixon, A. R., \& Telles, E. E. (2017). Skin color and colorism: Global research, concepts, and measurement. Annual Review of Sociology, 43(1), 405-424.

Doane, A. W., \& Bonilla-Silva, E. (2013). White out: The continuing significance of racism. New York, NY: Taylor and Francis.

Du Bois, W.E.B. (1915). The Negro. New York, NY: Henry Holt.

Dyer, R. (1997). White. New York, NY: Routledge.

Foster, M. (1997). Black teachers on teaching. New York, NY: The New Press.

Foucault, M. (1972). Archeology of knowledge. New York, NY: Pantheon Books. 
Frankenberg, R. (1993). White women, race matters: The social construction of Whiteness. Minneapolis, MN: University of Minnesota Press.

Garner, S. (2006). The uses of Whiteness: What sociologists working on Europe can draw from US research on Whiteness. Sociology, 40(2), 257-275.

Gay, G. (2010). Acting on beliefs in teacher education for cultural diversity. Journal of Teacher Education, 61(1-2), 143-152.

Gay, G. (2002). Preparing for culturally responsive teaching. Journal of Teacher Education, 53, 106-116.

Gillborn, D., \& Ladson-Billings, G. (Eds.) (2004). The RoutledgeFalmer reader in multicultural education (Readers in education). New York, NY: RoutledgeFalmer.

Glenn, E. (2009). Shades of difference: Why skin color matters. Stanford, CA: Stanford University Press.

González, N., Moll, L. C., \& Amanti, C. (2005). Funds of knowledge: Theorizing practices in households, communities, and classrooms. Mahwah, NJ: Lawrence Erlbaum Associates.

Grant, C., \& Ladson-Billings, G. (Eds.). (1997). Dictionary of multicultural education. Phoenix, AZ: Oryx Press.

Grant, C., \& Sleeter, C. (2006). Turning on learning: Five approaches to multicultural teaching plans for race, class, gender, and disability. Upper Saddle River, NJ: Prentice-Hall.

Guess, T. (2006). The social construction of Whiteness: Racism by intent, racism by consequence. Critical Sociology, 32(4), 649-673.

Hall, R. E. (2010). A historical analysis of skin color discrimination in America: Victimism among victim group populations. New York, NY: Springer.

Hill, M. (Ed.) (1997). Whiteness: A critical reader. New York: NY: New York University Press.

Irvine, J. J. (1990). Black students and school failure. Policies, practices, and prescriptions. Westport, CT: Greenwood Press.

Jacobson, M. F. (1998). Whiteness of a different color: European immigrants and the alchemy of race. Cambridge, MA: Harvard University Press.

Jones, T. (2013). The significance of skin color in Asian and Asian-American communities: Initial reflections. U.C. Irvine Law Review (3), 1105-1123.

Kang, H., \& Kim, I. (2012). Perceived and actual competence and ethnic identity in heritage language learning: A case of Korean-American college students. International Journal of Bilingual Education and Bilingualism, 15(3), 279294. 
Kang, M. (2015). Multicultural education in South Korea: Language, ideology and culture in Korean language arts education (Routledge Critical Studies in Asian Education). New York, NY: Routledge.

Keddie, A. (2012). Educating for diversity and social justice (Routledge Research in Education). New York, NY: Routledge.

Kim, D. (2015, May 7). How Jasmine Lee, one of the most hated women in Korea, is changing the country. The Huffington Post Korea. Retrieved from https://www.huffingtonpost.com/2015/05/07/jasmine-leekorea_n_7214186.html

$\mathrm{Kim}, \mathrm{H}$. (2012). Social and cultural issues in some EFL textbooks in Korea. Hawaii Pacific University TESOL Working Paper Series 10, 30-39.

Kim, J. C. (2010). Asian hair: A Korean study. In D. Pathomvanich \& K. Imagawa, Hair restoration surgery in Asians (pp. 21-22). Tokyo, Japan: Springer.

Kim, J. H. (2018, July 29). "Ya damunhwa"...Damimsaemeun nae chingureul iruhkae bulluyo [Hey, damunhwa...my homeroom teacher calls my friend this]. Seoul Shinmun. Retrieved from http://www.seoul.co.kr/news/ newsView.php?id=20180730013001\&wlog_tag3=naver

Kim, J. Y. (2019, May 19). Muslim hakseng manmyung shidae...gido gonggan mandeuneun daehakdeul [Era of 10,000 Muslim students... universities are making spaces for prayer]. Seoul Shinmun. Retrieved from https://www.seoul.co.kr/news/newsView.php?id=20190520011010\&wlog_t ag3=naver

Kim, J. I., \& Kim, M. (2016). Three Korean heritage language teachers' identities, their identification of their students, and their instructional practices. Journal of Language, Identity, and Education, 15(6), 361-375.

Kim, J. K., Basile, V., Jaime-Diaz, J., \& Black, R. (2018). "Internal Orientalism" and multicultural acts: The challenges of multicultural education in Korea. Multicultural Education Review, 10(1), 3-17.

Kim, J. R. (2018, December 27). Damunhwaeoneogangsayeonaphwui gidayasuko hwuijang "Chabyul daewoo chulpeheya" [Multicultural language instructor alliance president Gidayasuko says, "We must abolish discriminatory treatment"]. Yonhap News. Retrieved from https://www.yna.co.kr /view/AKR20181227073600371? input=1195m

Kim, K., Lee, K., \& Kim, T. (1981). Korean-Americans in Los Angeles: Their concerns and language maintenance. Los Angeles, CA: National Center for Bilingual Research.

Kim, M. (2019, July 23). Gyeolhonijuyeoseongdeul "Hanguk gukjeok eoddeotjiman...eommadeul dantokbange chode mothe [Marriage migrant women "Received Korean citizenship... but can't invite mothers to a group chat room"]. Hanguk Ilbo. Retrieved from https://www.hankookilbo.com/ News/Read/201907160875776629?did=NA\&dtype=\&dtypecode=\&prnewsi $d=$ 
Kim, N. (2014). Multicultural challenges in Korea: The current stage and a prospect. International Migration, 52(2), 100-121.

Kim, S. \& Kim, L. H. R. (2012). The need for multicultural education in South Korea. In D. Urias, The immigration and education nexus : A focus on the context and consequences of schooling (pp. 243-251). Rotterdam, The Netherlands: Sense Publishers.

Kim, Y. (2013). Multicultural education in social studies textbooks in South Korea and the United States: A comparative analysis. (Doctoral dissertation). University of Washington, Seattle, WA. Retrieved from https://digital.lib.washington.edu/researchworks/bitstream/handle/1773/23 623/Kim_washington_0250E_11613.pdf?sequence $=1$

Kivel, P. (1996). Uprooting racism: How White people can work for racial justice. Philadelphia, PA: New Society.

Korea Immigration Service (2018, June 19). Korea immigration service: Monthly statistics. Seoul, South Korea. Retrieved from http://www.moj.go.kr/doc_html/viewer/skin/doc.html?fn=82b1c994fb7b0a7 9aacb531ff4ff397f\&rs=/doc html/viewer/result/201809/

Kwon, Y. E. (2015, July 4). "Nan sal gachiga eubneun inganiehyo" maeumeui pimung ["I am a person unworthy to live" bruise in hearts]. Hankook-llbo. Retrieved from http://www.hankookilbo.com/News/Read/ 201507040492827227

Ladson-Billings, G. (1995). Toward a theory of culturally relevant pedagogy. American Educational Research Journal, 32(3), 465-491.

Ladson-Billings, G. (2004). New directions in multicultural education: Complexities, boundaries, and Critical Race Theory. In J. A. Banks \& C.A.M. Banks (Eds.), Handbook of research on multicultural education (2nd ed.) (pp. 50-65). San Francisco, CA: Jossey-Bass.

Lamoreaux, M., \& Morling, B. (2012). Outside the head and outside individualismcollectivism: Further meta-analyses of cultural products. Journal of CrossCultural Psychology, 43, 299-327.

Lee, G. W. (2015). Jeonsegye yeosung biyeul 22.3\%...Hanguk 16.3\%ro 111 we [Worldwide average percentage of women in politics $22.3 \%$...Korea at $16.3 \%$ ranking 111th in the world]. Yonhap News. Retrieved from http://www.yonhapnews.co.kr/bulletin/2015/09/06/0200000000AKR201509 06003600072.HTML

Lee, H. J. (2019, May 2). Hakpok chabyule nochuldwen damunhwa haksengdeul [Multicultural students that are exposed to school bullying and discrimination]. Seoul Shinmun. Retrieved from https://www.seoul.co.kr/news/newsView.php?id=20190503012003\&wlog_t ag3=naver 
Lee, J. S. (2002). The Korean language in America: The role of cultural identity in heritage language learning. Language, Culture and Curriculum, 15(2), 117133.

Lee, S. Y. (2018, June 21). Multicultural children face discrimination at schools. Korea Herald. Retrieved from https://www.koreatimes.co.kr/www/nation/ 2018/10/181_250993.html

Li, X. (2007). Multiculturalize teacher identity: A critical descriptive narrative. Multicultural Education, 14(4), 37.

Liu, L. (2015, May 5). Hangukne muslim shipyukmanmyung... pyungyuneurin shiseondeul [160,000 Muslims in Korea... receiving prejudiced looks]. SBS News. Retrieved from https://news.sbs.co.kr/news/endPage.do? news id=N1002961656

McIntosh, P. (1989, July/August). White privilege: Unpacking the invisible knapsack. Peace and Freedom Magazine, 10-12.

Ministry of Education (2017). Support plan for multicultural education in 2017. Seoul, South Korea. Retrieved from http://english.moe.go.kr/ boardCnts/view.do?boardID=265\&boardSeq $=70384 \&$ lev=0\&searchType $=$ S\&statusYN=C\&page $=1 \& s=$ english $\& m=0301 \&$ opType $=$

Ministry of Justice. (2016). 2015nyeon chulipgukja [Foreign population in 2015]. Retrieved from http://www.moj.go.kr/HP/COM/bbs_03/ShowData.do? strNbodCd=noti0005\&strWrtNo=3623\&strAnsNo=A\&strFilePath=moj/\&str RtnURL=MOJ_30200000\&strOrgGbnCd $=100000$

Muller, J. (2008). Us and them: The enduring power of ethnic nationalism. Foreign Affairs, 87(2), 18-35.

National Human Rights Commision of Korea (2002). Crepaseui 'salsaek' pyogineun pyeongdeunggwun chimhae [Marking crayons 'salsaek' is a violation of the rights of equality]. Seoul, South Korean. Retrieved from https://www.humanrights.go.kr/site/program/board/basicboard/view?\&boar dtypeid $=24 \&$ currentpage $=270 \&$ menuid $=001004002001 \&$ pagesize $=10 \&$ bo ardid $=554485$

Nieto, S. (1996). Affirming diversity: The sociopolitical context of multicultural education (2nd ed.). White Plains, N.Y.: Longman USA.

Ock, H. J. (2019, July 24). [Feature] Marriage migrants often at the mercy of Korean husbands. The Korea Herald. Retrieved from http://www.koreaherald.com/view.php?ud=20190724000709

Ock, H. J. (2018, January 3). Korean perceptions of migrant workers worsen: Survey. The Korea Herald. Retrieved from http://www.koreaherald.com/view.php?ud=20180103000696

Ock, H. J. (2015, September 9). Korea's wage gap between local, foreign workers largest in OECD. The Korea Herald. Retrieved from http://www.koreaherald.com/view.php?ud=20150909001162 
Oh, C. (2014). The politics of the dancing body: Racialized and gendered femininity in Korean pop. In Y. Kuwahara (Ed.), The Korean wave: Korean popular culture in global context (pp. 53-84). New York, NY: Palgrave Macmillan.

Oh, J., Kang, D. K., Shin, J. J., Lee, S. Lee, S. B., \& Chung, K. (2012). Migration profile of the Republic of Korea. IOM MRTC (IOM Migration Research and Training Centre). Retrieved from https://publications.iom.int/ system/files/pdf/mp_korea.pdf

Omi, M., \& Winant, H. (2015). Racial formation in the United States (Third ed.). New York, NY: Routledge/Taylor \& Francis Group.

Park, S. R. (2018, May 4). Salsaekgwa salgusaek ['Skin color-color and peach color]. Joongdo News. Retrieved from http://www.joongdo.co.kr/ main/view.php?key=20180513010004927

Park, S. E., \& Park, H. Y. (2018, March 5). Umma, seonsengnimi nareul 'damunhwa'ra bulreuyo [Mom, the teacher calls me 'damunhwa']. Yonhap News. Retrieved from https://www.yna.co.kr/view/AKR20180305 102400797? input=1195m

Pollock, M., Deckman, S., Mira, M., \& Shalaby, C. (2010). "But what can I do?": Three necessary tensions in teaching teachers about race. Journal of Teacher Education, 61(3), 211-224.

Presidential Commission for Social Inclusion (2006). Policies for social integration of foreign wives and their families: Report for the 74th National Meeting on April 26, 2006. Retrieved from www.pcsi.go.kr

Rieger, A. (2015). Making sense of White identity development: The implications for teacher education. Multicultural Learning and Teaching, 10(2), 211-230.

Roh, J. (2014). Korea's Employment Permit System and wage development of foreign workers. Public Policy and Administration Review, 2(3), 41-63.

Rondilla, J., \& Spickard, P. R. (2007). Is lighter better?: Skin-tone discrimination among Asian Americans. Lanham, MD: Rowman \& Littlefield.

Rothenberg, P., \& Munshi, S. (2016). White privilege: Essential readings on the other side of racism ( $5^{\text {th }}$ ed.). New York, NY: Worth.

Schulte. A. K. (2004). Examples of practice: Professional knowledge and self-study in multicultural teacher education. In J. J. Loughran, M. L. Hamilton, V. K. LaBoskey, \& T. Russell (Eds.), International handbook of self-study of teaching and teacher education practices (pp. 709-743). Dordrecht. The Netherlands: Kluwer Academic Publishers.

Shin, G. J. (2018, August 29). Shinsunham ilko juchumhaeddun yugayeneung, 'Damunhwa code'ro sae hwalro [Parenting entertainment shows that have lost novelty and have been slowing down...on a new pathway with the 'Damunwha code']. Dong-A llbo. Retrieved from http://news.donga.com/3/all/20180829/91724758/1 
Simpson, A. (2007). Language and national identity in Asia. Oxford. UK: Oxford University Press.

Telles, E., \& Paschel, T. (2014). Who is Black, White, or mixed race? How skin color, status, and nation shape racial classification in Latin America. American Journal of Sociology, 120(3), 864-907.

Tharps, L. (2016). Same family, different colors: Confronting colorism in America's diverse families. Boston, MA: Beacon Press.

Vavrus, M. (2009). Sexuality, schooling, and teacher identity formation: A critical pedagogy for teacher education. Teaching and Teacher Education, 25(3), 383-390.

Villegas, A. M., \& Lucas, T. (2002). Educating culturally responsive teachers: A coherent approach. Albany, NY: State University of New York Press.

Volodzko, D. J. (2017). Is South Korea ready to take on racism? First, it must admit it exists. South China Morning Post. Retrieved from https://www.scmp.com/week-asia/politics/article/2122913/south-koreaready-take-racism-first-it-must-admit-it-exists

Wan, C., \& Chew, P. (2013). Cultural knowledge, category label, and social connections: Components of cultural identity in the global, multicultural context. Asian Journal of Social Psychology, 16(4), 247-259.

Wellman, D. T. (1993). Portraits of White racism (2nd ed.). Cambridge, UK: Cambridge University Press.

Whiteness. (2018). In Oxford dictionaries online. Retrieved from https://en.oxforddictionaries.com/definition/whiteness

Wilson, J. (2002). Invisible racism: The language and ontology of 'White trash'. Critique of Anthropology, 22(4), 387-401.

Yeo, M. (2016). South Korean teachers' beliefs about diversity: The impact on practice of multicultural education (Doctoral dissertation). Portland State University, Portland, OR. Retrieved from https://pdxscholar.library.pdx.edu/cgi/viewcontent.cgi?article=4131\&contex $\mathrm{t}=$ open_access_etds

Yoon, H. G. (2018, October 4). Pibu kkamatago nollim danghan 'honhyeolah' yeosungi $L G$ deukbunae chodeunghakgyo gyosaga dwen sayeon [The story of how the 'mixed-race' woman who was teased for having black skin became an elementary school teacher]. Insight. Retrieved from https://www.insight.co.kr/news/182156

You, B. K. (2005). Children negotiating Korean American ethnic identity through their heritage language. Bilingual Research Journal: The Journal of the National Association for Bilingual Education, 29(3), 711-721. 


\section{Author Contact}

Hyein Amber Kim: hkim55@buffalo.edu

Linguistics Department, Buffalo, NY 14260, U. S. A. 